高度不飽和脂肪酸の高度精製技術

山村 隆治・下村 泰志

(株)ワイエムシィ

（干600-8106 京都市下京区五条烏丸西入醍醐町 284）

\title{
High Purification of Polyunsaturated Fatty Acids
}

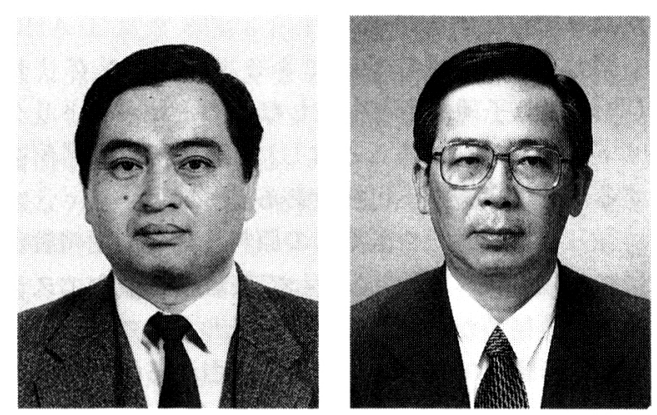

\author{
Ryuji Yamamura and Yasushi Shimomura \\ YMC Co. Ltd.
}

(284, Daigocyo, Gojyou-Karasumanishiiru, Shimogyo-ku, Kyoto-shi 600-8106)

\begin{abstract}
Polyunsaturated fatty acids (PUFA), including eicosapentaenoic acid (EPA), docosahexaenoic acid (DHA) and docosapentaenoic acid (DPA), are of particular interest for the potential applications to functional diets and medication, which would require a high degree of purity.

Considerable effort has been directed to the purification of PUFA. EPA has been fully purified on an industrial scale.

The purification of PUFA is difficult due to the numerous complex processes required. A large scale purification still remains to be fúlly realized.

Esterified single cell oil containing high DHA and DPA content was purified in the present study by an industrial scale high-performance liquid chromatography (HPLC) plant using ODS columns. Highly purified DHA-E and DPA-E were obtained in a one-step process.
\end{abstract}

Key words : PUFA, purification, EPA, DHA, DPA, single cell oil, HPLC

\section{1 はじめに}

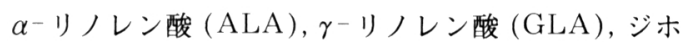

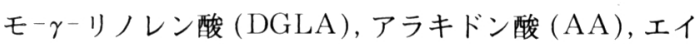
コサペンタエン酸 (EPA), ドコサヘキサエン酸(DHA) やドコサペンタエン酸 (DPA) を含む高度不飽和脂肪酸 (PUFA) はその生理活性から機能性食品や医薬品とし て注目を浴びている ${ }^{1) \sim 5) 。 ~}$

それにつれ, その供給源が探索され, 魚油, 植物, 微 生物, 原生動物, 藻類まで供給源が広がっている。

また卵黄中のリン脂質（レシチン）にも多種の PUFAが含まれている6)。

供給源により, PUFA の組成は大きく異なり，また 複数の PUFA が混在している。

\section{連絡者：下村泰志}

連絡先: 干923-0061 石川県小松市国府台 5-28

(株)ワイエムシィ S\&S 事業部

(5-28, Kokufudai, Komatsu-shi, Ishikawa-ken 923-0061)
それぞれの PUFA の生理活性はかなりの相違点があ り，優れた機能を発揮するためには，単一のPUFA に 分離することが好ましい。特に医薬品の場合は更なる高 純度が求められる。

現在, EPA や DHA の工業的製造は魚油を原料とし て行われているが, 魚油中の EPA や DHA の含量は特 殊な部位を除いては 10〜20\%である。

微生物の培養による油脂生産は, 生産性が自然条件に 左右されないこと, 増殖速度が大きく生産量のコント ロールが容易であること等から, 油脂原料の工場生産に 直結する夢の技術として考えられてきた 7$) 。$

PUFA の微生物生産は GLA, AA について実用生産 が始められている。PUFA の微生物による生産は, 動 植物油脂資源からは得にくい各種 PUFA を効率よく生 産できる可能性があり, 微生物によって作られるユニー クな油脂は, Single Cell Oil との呼び名が与えられる ようになっている8)。また DHA の含量として 30〜50 \%を越す微生物が見いだされている9),10)。

PUFA は, 供給源によらず脂質あるいはリン脂質の 
かたちで存在する。

同じ PUFA を分子内に 3 モル含むトリグリセリド (TG) の分子種は殆ど存在しないことから，トリグリセ リドを加水分解することなしに高純度の PUFA を製造 することは事実上不可能である。

従って標準試料や医薬用の原料などの高度精製が必要 になる場合は，TG から離して遊離脂肪酸やエステルと して分離精製が行われる。エステルとしては生体への安 全性を考慮してエチルエステル化される場合が多い。

\section{2 精製方法}

高度不飽和脂肪酸の分離精製のため検討されてきた方 法は, 化学的, 物理的観点から以下のように分類するこ とができる。

PUFA を化学的反応を利用して分離する方法

醉素による選択的加水分解

酔素による選択的エステル化

銀錯体形成

尿素包接形成

ヨードラクトン化

PUFA 自体の物性で分離する方法

蒸留（精密蒸留, 分子蒸留)

溶剤低温分別（ウインタリング）,

低温分別結晶化

PUFA と媒体との相互作用で分離する方法

クロマトグラフィ

膜分離

抽出（液一液分配）

PUFA の分離には, TG 中の特定 PUFA 成分を濃縮 する段階のものから，特定の PUFA を高度に分離精製 する段階のものまで多岐にわたる。

\subsection{TG 或いは高度不飽和脂肪酸の濃縮}

TG 中の不飽和脂肪酸の濃度を高めるための濃縮方法 としては，酵素を用いた加水分解による濃縮 ${ }^{11) ~ 13) ， ~}$

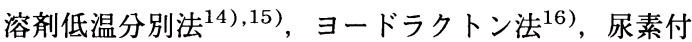

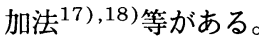

\subsection{TG 或いは遊離高度不飽和脂肪酸の高度精製}

TG や遊離脂肪酸として PUFA を高度に精製する方 法としてはリパーゼを利用するもの，前処理した後，液 体クロマトグラフィを行うもの等が検討されている。

$2 \cdot 2 \cdot 1$ リパーゼによる選択的エステル化

リパーゼを触媒として，マグロ油由来の脂肪酸をラウ リルアルコールで選択的にエステル化し，末反応脂肪酸 分画の DHA 含量を $90 \%$ 以上まで高め, 脂肪酸として の DHA を高純度に得ている19) 21)。

\section{$2 \cdot 2 \cdot 2$ リパーゼによる選択的加水分解}

リパーゼを用いた加水分解反応により，PUFA をグ リセリド骨格に残し，次いで，液一液抽出と膜分離を組
み合わせて, 遊離した脂肪酸を分離し, PUFA に富ん だ TG の取得を試みている ${ }^{22)}$ 。リパーゼの脂肪酸の結 合位置を認識する位置特異性と構成脂肪酸の種類により 加水分解活性の相違を利用して, TG 中の PUFA の含 有率を高める。得られた加水分解油を $75 \%$ エタノール 水溶液で液一液抽出を行い，その溶媒相をポリイミド UF 膜により系外に出す。加水分解油から効率的に遊離 脂肪酸を除去し，PUFA の濃縮されたグリセリドを得 ている。

\section{$2 \cdot 2 \cdot 3$ 低温抽出法}

液体窒素中へ魚油を滴下し急速固化を行った魚油粒子

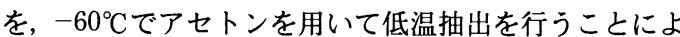
り, TG 中の PUFA 含量の多い TG を得るという簡単 な濃縮法が提案されている23)。いわし油で EPA と DHA の合計含量を 1.54 倍に濃縮している。回収率は $26 \%$ ある。

\section{$2 \cdot 2 \cdot 4$ ポリマー系液体クロマトグラフィ}

培養ユーグレナ（藻類）を加水分解して得た遊離脂肪 酸を，ウインタリングし，ワックスエステルを除いた 後，ポリマー系 (DS-2013) の充填剤，95\%アセトニト リルを使用した High Performance Liquid Chromatography (HPLC) により AA の分取 (分離精製) を行い，純度 $99 \%$ の精製品が，70\%の回収率で得られ ている ${ }^{24)}$ 。

\section{$2 \cdot 2 \cdot 5$ 逆相系 ODS 液体クロマトグラフィ}

$\mathrm{EPA}$ を産生する微細藻類を直接簽化して, 脂肪酸を 抽出し, 次いで尿素付加法によって, EPA 1.73 倍 (55.2/31.9) 濃縮し, 内径 $10 \mathrm{~mm}$, 長さ $250 \mathrm{~mm}$ の ODS カラムでメタノール/水 $(80 / 20)$ を溶離液として精 製されている25)。EPA の純度 $93.4 \%$, 全体としての回 収率は $65 \%$ であった。

\section{$2 \cdot 2 \cdot 6$ 超臨界流体抽出}

超臨界流体抽出法 (SFE)，特に二酸化炭素を用いた場 合，操作温度を常温近傍とすることができ，無酸素下で 操作できるので熱劣化や酸化されやすい物質を処理する には有効である。PUFA の SFE には殆どの場合, 超 臨界流体として二酸化炭素が使用されている。

二酸化炭素を用いた超臨界流体による抽出及び ODS カラムの超臨界クロマトグラフィとの組み合わせで, ALA を豊富に含むエゴマを原料とし，トリグリセリド のままでの濃縮が検討されている ${ }^{26)}$ 。

\section{$2 \cdot 3$ 高度不飽和脂肪酸エステルの高度精製}

高純度の PUFA を取り出すためには，TG を加水分 解，エステル化し PUFA のエステル (PUFA-E) とし て分離される場合が多い。PUFA をエステルにして分 離する技術としては硝酸銀水溶液による抽出, 精密蒸 留, クロマトグラフィ等があげられる。

しかし原料が魚油由来の PUFA-E は非常に複雑な混 
合系であり，また性質の類似した夾雑物が存在するため 複数の分離手段を組み合わせて分離精製される場合が多 い。

\section{$2 \cdot 3 \cdot 1$ 硝酸銀水溶液による選択的抽出}

二重結合を含む分子が銀塩水溶液中で, 銀塩と錯体を 形成することで水溶性化する。二重結合が多いほど溶解 度が増加する 27 。

硝酸銀水溶液による PUFA-E の選択的抽出は種々検 討 ${ }^{28) ~ 32) さ れ て い る 。 ~}$

例えば 28.8 及び $45.6 \%$ DHA-E を原料にし硝酸銀 水溶液による選択的抽出が行われている。原料のトルエ ン溶液と硝酸銀水溶液を接触させ錯体形成し, 錯体水溶 液をトルエン抽出する。95\%以上の DHA-E を得てい $3^{33), 34) 。}$

硝酸銀は高価であり，腐食作用があるため, 装置の工 夫が必要である。

\section{$2 \cdot 3 \cdot 2$ 高真空精留}

高真空蒸留法は, 魚油の工業的精製に一般に用いられ ているが, PUFA の精製に適応するには, 多成分混合 物であるため, 高い分離効率を要し, またできるだけ低 い温度で蒸留する必要がある。

秦ら ${ }^{35), 36)}$ はEPA の医薬品としての開発を目的に, 魚油脂肪酸エチルエステルを高真空下での精密蒸留と尿 素付加法の組み合わせで $90 \%$ 以上の EPA エチルエス テル $(\mathrm{EPA}-\mathrm{E})$ に精製している。

精密精製には 4 塔式連続精製装置 Fig. 137)を用い, 原料中の $18 \%$ の EPA-E を $83 \%$ まで濃縮している。尿 素付加も尿素を繰り返し使用できる連続装置を開発し， 2 つの方法の組み合わせで $90 \%$ 以上の EPA-E を得て いる。

EPA-E の場合には，90\%程度の純度で医薬品として の承認を得たが, DHA の場合はおそらく95\%以上の高 純度が必要であると言われている38)。

DHA を含むマグロ油エチルエステルを精留塔の塔頂 の真空度 0.01 torr, 精留塔頂内蒸気温度 $136^{\circ} \mathrm{C}$ で蒸留
し， DHA-E 純度 85\%を得ている ${ }^{39)}$ 。脂肪酸エチルエ ステルは分子量が大きくなるに従い高い温度で留出す る。しかし炭素数が同じで二重結合数が異なるものは, その留出挙動は同じとなる。

同様な方法で得られた精留 DHA 純度 76\%を，七ミ 分取 ODS カラムを用い, メタノールを移動相にして最 高純度 $97.8 \%$ のHA-E を得ている。その時の回収率 は 47\%であった。真空蒸留の過程で DHA-E の濃縮と ともに熱変成物が生成し，分取クロマトグラフィでも除 去できていない。

$2 \cdot 3 \cdot 3$ 分子蒸留法

マグロ油エチルエステルを原料にして, 遠心薄膜式分 子蒸留機を用いた蒸留試験が検討されている ${ }^{40)}$ 。DHA 含量 24〜27\%のマグロ油エチルエステルをDHA の純 度 70\%以上に濃縮している。その回収率は 20〜 40\% で，再蒸留を行うことにより全体で $50 \%$ となった。こ の遠心薄膜式分子蒸留して得られた DHA-E 分画を （DHA-E 組成比約 70\%）を出発物質として ODS 充媜 剂を充媜した内径 $100 \mathrm{~mm}$, 長さ $300 \mathrm{~mm}$ のカラムを 使用し，移動相としてメタノール，あるいは水を添加し た系で分取液体クロマトグラフィを行っている。メ夕 ノール $100 \%$ で，純度 $96.1 \%$, 回収率 52\%, メ夕ノー ル/水 (90/10) で, DHA-E 純度 $98.0 \%$, 回収率 43\%の 結果を得ている。ここで水の添加量を增すことにより, DHA-E 純度は向上すると推定しているが, 1 回の処理 時間が延長し, 回収率も低下すると述べている。分子蒸 留法では, 真空蒸留法で生成した DHA-E 由来の熱変 成物は生成していない。

また分子蒸留法により精製した PUFA から残留溶剂 の除去や極性不純物 ${ }^{41)}$ の除去が行われている。

$2 \cdot 3 \cdot 4$ 超臨界流体抽出 (SFE)

$\mathrm{SFE}$ のみで魚油等の複雑な混合物から, 特定の EPA やDHA の成分を高純度に分離するのは殆ど不可能で ある。

蒸留, 銀錯体形成, 尿素付加等の精製方法と SFE を

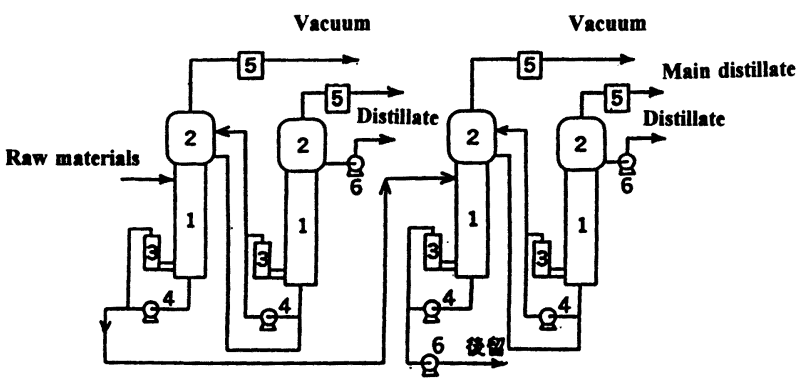

Fig. 1 Rectification apparatus.

1 : Rectification tower ; 2 : Condenser ; 3 : Rebioler ;

4 : Circulating pump ; 5 : Cold trap ; 6 : Pump 
組み合わせた方法が提案されている。

蒸留操作と二酸化炭素を用いた SFE を組み合わせ て, EPA を 6.5\%含む魚油を純度 $48.2 \%$, 回収率 $77 \%$ の濃縮が行われている ${ }^{42)}$ 。炭素数の 2 個違う脂肪酸工 ステル類は良く分画されているが，しかし同じ炭素数で 不飽和度の異なる $\mathrm{C} 20: 1$ と $\mathrm{C} 20: 5(\mathrm{EPA})$ の分画は余り 良くない。

また温度勾配を付した SFE 塔を用いて魚油エチルエ ステルの濃縮が行われている ${ }^{43)}$ 。抽出塔の高さ方向に 塔上部ほど溶解度を減少させるように温度勾配を与える 多段分離法である。魚油の脂肪酸エステルの濃縮は可能 であり, EPA, DHA については, 天然由来の原料で も, その原料組成の選定と尿素処理等の前処理を行うこ とにより $90 \%$ 以上の精製も可能である。

抽出装置内にシリカゲルに硝酸銀を担持した分離チャ ンバーを組み入れた二酸化炭素 SFE を用いて, DHA のメチルエステル (DHA-M) の選択的抽出分離を行っ

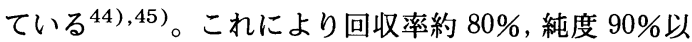
上の DHA-M を得ている。

硝酸銀水溶液と魚油エチルエステルで錯体を形成さ せ, 不飽和度の高い脂肪酸エステル(EPA-E, DPA-E) を水溶液に分配した後, その水溶液を超臨界二酸化炭素 で抽出する方法が提案されている46)。EPA-E が抽出 初期において約 $60 \mathrm{wt} \%$ ものが得られ, DPA-E は抽 出後期で $90 \mathrm{wt} \%$ 以上のものが得られている。また銀は 再生可能である。

エチルエステル化したにしん油を原料とし, 尿素と包 接化し飽和脂肪酸等を除去した後, 二酸化炭素による $\mathrm{SFE}$ を行い EPA-E 及び DHA-E を 90\%以上の純度 で得ている ${ }^{47) 。}$

\section{2・3・5 クロマトグラフィ法}

クロマトグラフィ法は, 分離の分解能が良好なことか ら, 従来から PUFA の分離精製の可能性について注目 されていた。EPA の場合に採用された精密蒸留法で は，より分子量が高く蒸留温度も高く熱的に問題がある DHA を高度に精製するにはカラムクロマトグラフィ法 が適していると考えられる。しかし工業的規模で精製を 行うには, 大量に使用する溶剤の回収法や負荷量の増量 についての問題が有ったが, 最近になって工業的規模で の可能性が見いだされるようになってきている。

$2 \cdot 3 \cdot 5 \cdot 1$ 遠心液一夜分配クロマトグラフィ $(\mathrm{CPC})$

遠心液一液分配クロマトグラフィ $(\mathrm{CPC})^{48)}$ は固定充 填剂を使用せず，二層液系のみで分離精製を行う向流分 配クロマトグラフィの一種で, 遠心力を利用することに より, 分離時間の短縮, 高性能化を可能にするものであ る。

$\mathrm{AA}$ を産生する培養菌体からエステル化工程を経て得 られた原料及び微生物起源のジホモ- $\gamma$-リノレン酸
(DGLA) エチルエステルが CPC を用いて分離精製さ れている ${ }^{49)}$ 。AA の場合へキサン/アセトニトリル（1/ 1) の分離で純度 $90.8 \%$, 回収率 $82 \%$,これをへキサン/ アセトニトリル/水 $(10 / 9 / 1)$ で処理した結果, 純度 $98.8 \%$, 回収率 $50 \%$ となっている。自動連続運転では最 終的には $99.8 \%$ の純度のものが得られている。また DGLA ではへキサン/アセトニトリル $(1 / 1)$ の処理と ヘキサン/メタノール/水 $(10 / 9 / 1)$ の系の組み合わせで 最終的には 99.5\%の DGLA が得られている。

$2 \cdot 3 \cdot 5 \cdot 2$ ポリマー系液体クロマトグラフィ

ポリマー系充填剂を用いた工業規模の二酸化炭素超臨 界クロマトグラフィ (SFC) を使用し，魚油メチルエス テルを尿素処理することにより EPA メチルエステル (EPA-M) を 43.6\%に濃縮した脂肪酸メチルエステル を出発物質とした分離精製が行われている50)。純度 $90 \%$, 回収率 60\%の $\mathrm{EPA}-\mathrm{M}$ を得ている。

$2 \cdot 3 \cdot 5 \cdot 3$ 銀担持充媜剤を用いたクロマトグラフィ 不飽和結合を有する有機化合物とある種の金属イオン が $\pi$-錯体を形成する。中でも銀イオンが $\pi$-錯体形成能 が大きく, シリカゲル，ゼオライトに銀イオンを担持さ せた充填剤を用いた不飽和化合物を分離する配位子交換 クロマトグラフィが知られていた。この方法は飽和と不 飽和化合物の分離には有効な方法であるが, PUFA 相 互間の分離は良好でないことや, PUFA の負荷量がそ れ程多くない。

メチルエステル化した魚油を二酸化炭素 SFE と硝酸 銀担持シリカ充填剤を使用した二酸化炭素 SFC を連続 的に組み合わせて $\mathrm{EPA}-\mathrm{M}$ と DHA-M の精製が行われ ている51)。

$\mathrm{SFC}$ はカラム出口の圧力を段階的に減少させること により達成している。EPA-M, DHA-M はそれぞれ 12\%から 93\%に，13\%から 82\%に精製されている。

井上ら ${ }^{52)}$ は銀担持シリカと硝酸銀水溶液を用いた抽 出の二つの分離法に注目し新夕イプの含水硝酸銀付加シ リカゲル素材を開発し，PUFA-E をへキサン及び酷酸 エチルでオープンカラム・クロマトグラフィを行い, 99\%の EPA-E を得ている。

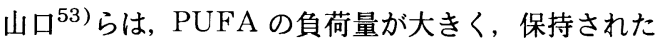
銀イオンが使用中に溶離液中へ溶出することがない球状 粘土鉱物の相間に銀をイオン交換した銀担持球状粘土鉱 物が不飽和度の異なる脂肪酸を選択的に識別する能力を 有することを見いだした。

これを充填した内径 $100 \mathrm{~mm}$, 長さ $100 \mathrm{~mm}$ のカラ ムを用い，魚眼窩油のエチルエステルをアセトン/n-へ キサン溶液をステップワイズ溶出分離を行い，最終的に は99.0\%の DHA-E を得ている。

更に, この担体を超臨界流体クロマトグラフィ $(\mathrm{SFC})$ に用いて, 高純度の DHA-E を得る方法が見い 


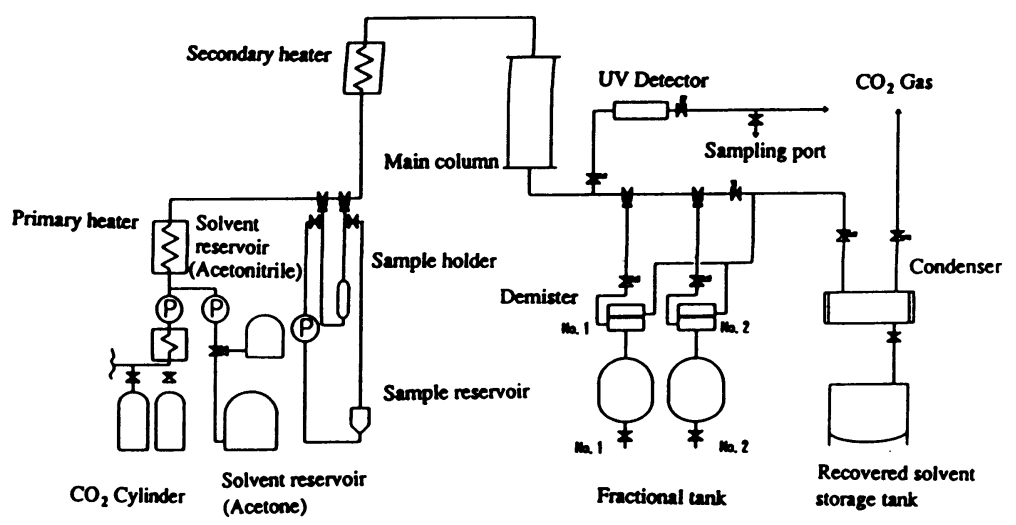

Fig. 2 Flow Diagram of Pilot-Scale SFC.

だされている54),55)。

$\mathrm{DHA}-\mathrm{E}$ を $28 \%$ 含有する魚油エチルエステルを原料 とし, 銀担持球状粘土鉣物を充填した内径 $50 \mathrm{~mm}$, 長 さ $100 \mathrm{~mm}$ と内径 $50 \mathrm{~mm}$, 長さ $50 \mathrm{~mm}$ の 2 本のカラ ムを用い，モディファイヤーとしてアセトンとアセトニ トリルをグラジェントで使用したパイロットスケールの 超臨界二酸化炭素クロマトグラフィ (Fig. 2) を行って いる。純度 $99 \%$ 以上の DHA-E を約 $65 \%$ の回収率で得 ている ${ }^{56) 。}$

$2 \cdot 3 \cdot 5 \cdot 4$ 逆相系 ODS 液体クロマトグラフィ

筆者ら ${ }^{57)}$ は海生菌の培養菌体 (Schizochytrium sp. SR 21) から得られた DHA 及び DPA を含有する Sin-

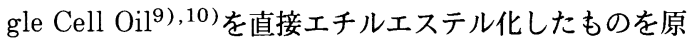
料として, ODS カラムによる工業的規模の分取クロマ トグラフィを使用して DHA-E 及び DPA-E の分離精 製を行った。
原料の Single Cell Oil エチルエステル (Single Cell Oil-E) の分析クロマトグラムをFig. 3 に示す。比較の ためかなりの程度精製された魚油エチルエステル (DHA-60 E, 日本化学飼料製, DHA-E 含量 $66.7 \%$, EPA-E 含量 $14.9 \%$ ) のクロマトグラムを示す。この Single Cell Oil はDHA および DPA をそれぞれ約 $35 \%, 7 \%$ 含有している。

Single Cell Oil-E は魚油エチルエステルに比較して 夾雑物が少ないことが判る。特に目的ピーク近傍の夾雑 物ピークの数が少なくその距離も離れており, その量 （ピーク高さ）も小さい。目的ピーク近傍の夾雑物ピー クの有無やその量は, 高純度・高回収率で分取クロマト を行う場合の生産性（負荷量）に大きく影響する。

Single Cell Oil における主要成分である DHA-E と DPA-E のピークの分離係数 $(\alpha 3)$ は 1.291 である。ま た魚油においては EPA-E と DHA-E の間の分離係数
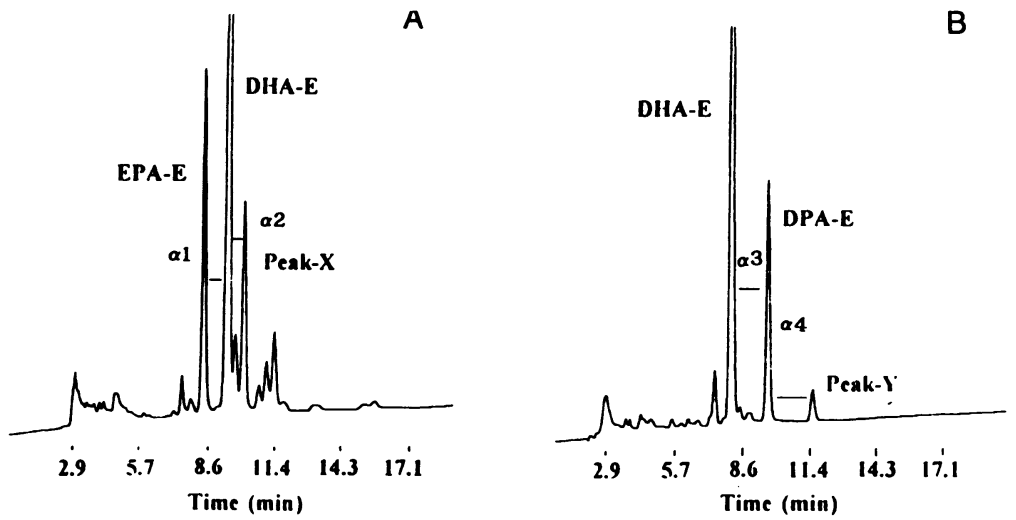

Fig. 3 High-performance liquid chromatograms of esterified fish oil (A) and esterified single cell oil (B).

$\alpha 1$ : Separation factor (SF) between EPA-E and DHA-E; $\alpha 2:$ SF between EPA-E and Peak-X in fish oil ; $\alpha 3$ : SF between DHA-E and DPA-E ; $\alpha 4$ : SF between DPA-E and Peak-Y in esterified single cell oil ; Peak-X and Peak-Y, unknown components. 


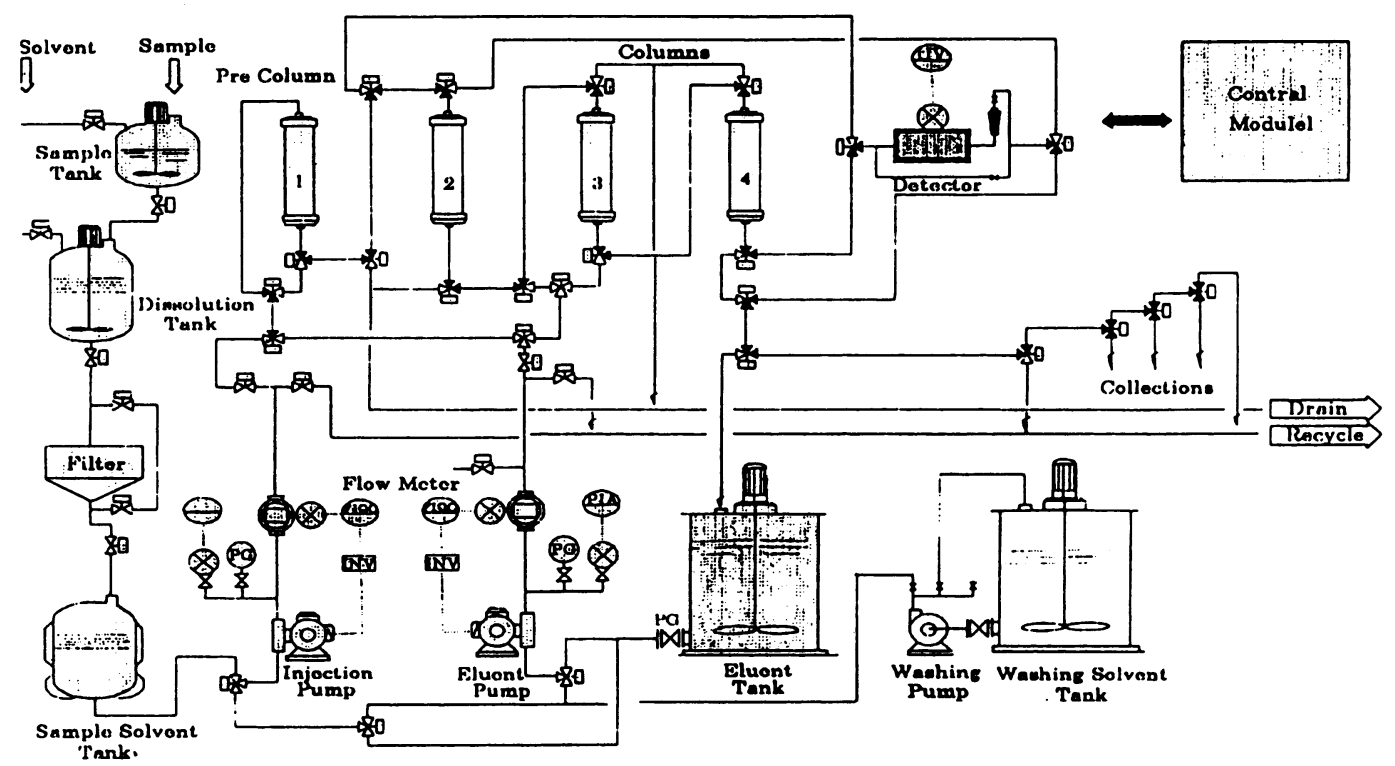

Fig. 4 The Flow diagram of industrial preparative HPLC.

PIA, PG, INV, and FIQC mean respectively, pressure indicator alarm, pressure gauge, inverter, and flow indicator control.

( $\alpha 1)$ は 1.189 あった。

目的ピーク近傍の夾雑物ピークと各成分間の分離係数 から, Single Cell Oil-E が魚油エチルエステルより HPLCでは精製しやすいことを意味している。

工業的分取 HPLC プラントは ODS 充填剤 (YMCGel ODS AM 120-S50) を充填した, 内径 $400 \mathrm{~mm}$, 長 さ $1000 \mathrm{~mm}$ のカラムを 2 本から構成されている。

その構成図を Fig. 4 に示す（本プラントでは 4 本の カラムが使用可能であるが，本精製には 2 本のカラムを 使用)。プラント全体は完全防爆仕様で, システム全体 はコンピューターにより完全に管理・制御される。また 溶剤の回収のための蒸留塔を装備している。

溶離液としては, メタノール/水系で予備検討を行い, 99\%以上の高純度 DHA-E 及び DPA-E を得る場合,

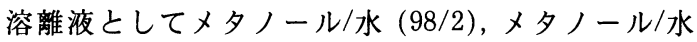
(96/4), メ夕ノール/水 $(100 / 0)$ の順で負荷量を多くす ることができた。そこで, 溶離液としてはメタノール/ 水 $(98 / 2)$ を用いた。

Single Cell Oil-E のメタノールの 10\%溶液を試料溶 液として, 負荷量 $1.33 \mathrm{~kg} /$ サイクル, 溶離液の流速 4.4 L/分で分取を行った。分取時間は 120 分であった。

高純度品を得るための分取クロマトグラフィの場合, 目的フラクションをどのようなタイミングで切り分ける かが重要なポイントとなる。純度及び回収率は, その夕 イミングで変動する。そのタイミングを知るためにでき るだけ細かくフラクション分けを行い，その純度と回収
量から得られた DHA-E と DPA-E の純度と回収率の 関係を Fig. 5 に示す。

純度 $99 \%$ 以上の DHA-E 及び DPA-E を得る場合, その回収率は $23.2 \%, 79.6 \%$ でった。また，その純度 が 98\%の場合, DHA-E 及び DPA-E の回収率は 70 \%, 96\%であった。

Single Cell Oil-E を原料とし, 溶離液としてメ夕 ノール/水 (98/2) を用いることにより, 純度と回収率が 高く, 生産性 (負荷量/サイクル時間) が高い, DHA-E

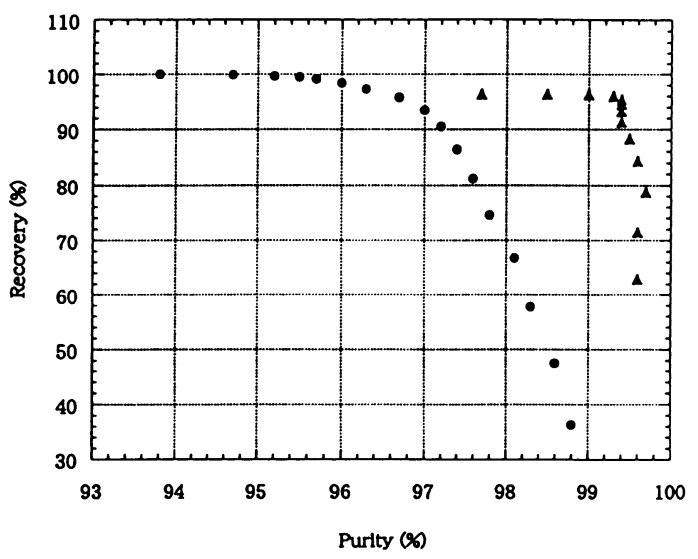

Fig. 5 The relationships between purities and recoveries of DHA-E and DPA-E. () : DHA-E, ( $\mathbf{\Delta}): \mathrm{DPA}-\mathrm{E}$ 
と DPA-E の分取を行うことができた。

原料として使用した Single Cell Oil は魚油に比較し

て, 高度不飽和脂肪酸含量の高さと夾雑成分の HPLC 挙動の観点から $\mathrm{DHA}-\mathrm{E}$ と DPA-E の高純度品を得 るための良好な供給源と思われる。

ODS カラムによる分取 HPLC は多くの医薬品製造 に使用されている実績があり, また工業レベルの分取 (分離精製) のための HPLC の運転条件は, 分析用 HPLC で充填剤の種類, 溶離液や検出器の検討を, 七 ミ分取 HPLC で負荷量, 純度, 回収率, 製品の回収方 法, 溶剤の回収方法を検討することにより, 比較的容易 に設定できる。

Single Cell Oil を原料とすることで, 精製手段とし て分取クロマトグラフィのみにより工業的な規模で, 高 度に分離精製された DHA-E と DPA-E が得られる可 能性が見いだされた。

\section{3 おりに}

不飽和脂肪酸の高度精製, 特に工業的規模の大量精製 の場合, 出発原料そのものに由来する共存成分の種類及 びその性質と目標とする純度に応じた総合的な精製技術 の開発が必要となる。

（受付：1998 年 1 月 8 日, 受理； 1998 年 2 月 20 日）

\section{文 献}

1) P. McLennan, P. Howe, M. Abeywardena, R. Muggli, D. Raederstorff, M. Mano, T. Rayner, R. Head, Europ. J. Parmacol., 300, 83 (1996).

2) J.S. O’Brien, E.L. Sampson, J. Lipid Res., 6, 545 (1965).

3）豊田淑江，森田育男，金田誠逸，脂質栄養学， 5, 17 (1996).

4) 知澤一良, ファルマシア, 31, 42 (1995).

5) 近藤和雄, 岩本珠美, 油化学, 46, 1195 (1997).

6) L.R. Juneja, "Hen Eggs", CRC Press, New York (1996), p. 73.

7) 鈴木 修, 油化学, 41, 779 (1992).

8) 横地俊弘, 油化学, 46, 1275 (1997).

9) T. Nakahara, T. Yokochi, T. Higashihara, S. Tanaka, T. Yaguchi, D. Honda, J. Am. Oil Chem. Soc., 73, 1421 (1996).

10) T. Yaguchi, S. Tanaka, T. Yokochi, T. Nakahara, T. Higashihara, J. Am. Oil Chem. Soc., 74. 1431 (1997)

11) 戸谷洋一郎, 月刊フードケミカル, 9, 37 (1993).

12）山根恒夫, 農化, 69, 791 (1995).

13）田中幸久, 船田 正, 油化学, 43, 39 (1994).

14）露木英太, “総合脂質化学”, 恒星社厚生閣, (1989), p. 64.

15) T. Yokochi, M.T. Usita, Y. Kamisaka, T. Nakahara, O. Suzuki, J. Am . Oil Chem. Soc., 67, 846 (1990).

16) N.V. Gaiday, A.B. Imbs, D.V. Kuklev, N.A.
Latyshev, J. Am. Oil Chem. Soc., 68, 230 (1991).

17) W.M.N. Ratnayake, B. Olsson, D.M. Matthews, R.G. Ackman, Fat. Sci. Technol., 90, 381 (1988).

18) K. Arai, S. Saito, Proc. of the World Congress III of Chem. Eng. Tokyo, 152 (1986).

19) Y. Shimada, K. Maruyama, S. Okazaki, M. Nakamura, A. Sugihara, J. Am. Oil Chem. Soc., 71, 951 (1994).

20) Y. Shimada et al, J. Am. Oil Chem. Soc., 74, 97 (1997).

21）丸山一輝, 島田裕司, 森山茂, 杉原 雄, 富永嘉男, “第 36 回油化学討論会講演要旨集”, p. 99 (1997).

22）鈴木一昭, 小池誠治, 石塚浩敏, 佐藤裕子, “機能性食 品素材の高度分離・精製と開発”, 食品産業ハイセパ レーション・システム技術研究組合, (1992), p. 383.

23) C.F. Moffat, A.S. Mcgill, R. Hardy, R.S. Anderson, J. Am. Oil Chem. Soc., 70, 133 (1993).

24）岩崎泰介, 藤田 孝, 柳下まゆ美, 皆川憲夫, 森口宏 康, 佐藤元昭, 守永絵里子, 山田 強, 森口征矢生, “機能性食品素材の高度分離・精製と開発”, 食品産業八 イセパレーション・システム技術研究組合, (1992), p. 363.

25) M. Cartens, E.M. Grima, A.R. Medina, A.G. Gimenez, J.I. Gonzalez, J. Am. Oil Chem. Soc., 73, 1025 (1996).

26) 喜古典雄, 川名秀明, 佐藤雄士, 鴻池達男, 清家邦彦, 満上生昌太, 福里隆一, 西口信彦, 井川 昇, 長瀬佳 之, 亀井義文, “機能性食品素材の高度分離・精製と開 発”, 食品産業ハイセパレーション・システム技術研究 組合, (1992), p. 285.

27) M. Teramoto, H. Matsuyama, N. Ohnisi, S. Uwagawa, K, Nakai, Ind. Eng. Chem. Res., 33, 341 (1994).

28) 西 康隆, “化学工学 56 年会要旨集”, 65 (1991).

29）矢澤一良, 景山治夫, 油化学, 40, 974 (1991).

30）三澤嘉久, 酵素工学ニュース, 30, 19 (1993).

31) 日本化学飼料, “DHA 高度精製抽出技術開発事業研究 報告書平成 4-6 年度”, (1996), p. 225 .

32）寺本正明, 松山秀人, 分離技術, 24, 146 (1994).

33）三澤嘉久, Harima Q, 33, 17 (1992).

34）百合忠彦, 畑 憲明, 三澤嘉久, “DHA 高度精製抽出 技術開発事業研究報告書平成 7-8 年度”, (1997), p. 103.

35) 秦 和彦, 月刊フードケミカル, 7, 36 (1991).

36）藤田孝夫, 日水誌, 61, 490 (1995).

37) 野田秀夫, 野田泰夫, 秦 和彦, 藤田孝夫, 化学工学, 55, 623 (1991).

38）矢澤一良, “バイオセパレーションプロセス便覧”, 化学 工学会「生物分離工学特別研究会」編, 共立出版, (1996), p. 202.

39）マルハ, “DHA 高度精製抽出技術開発事業研究報告書 平成 4-6 年度”, (1996), p. 213 .

40）古賀 毅, 昌子 有, 馬場貴司, “DHA 高度精製抽出 技術開発事業研究報告書平成 7-8 年度”, (1997) p. 83.

41）久保田紘二, 阿部 島, 阿部秀一, “DHA 高度精製抽 出技術開発事業研究報告書平成 7-8 年度”, (1997), p. 39.

42）斉藤功夫, 食品工業, 9 下, 37 (1984).

43）鈴木康夫, 今野政憲, 新井邦夫, 斉藤正三朗, 化学工学 論文集, 15, 439 (1989). 
44) 生島 豊, 畑田清隆, 斉藤功夫, 伊藤祥太, 後藤富雄, 化学工学論文集, 15, 511 (1989).

45）生島 豊, ファインケミカル, 20, 5 (1991).

46）鈴木 建, 菊池 智, 中野 薰, 加藤 覚, 長浜邦雄化 学工学シンポジュームシリーズ, 35, 161 (1993).

47) W.B. Nilsson, E.J. Gauglitz Jr., J.K. Hudson, V.F. Stout, J. Spinelli, J. Am. Oil Chem. Soc., 65, 109 (1988).

48）村山 弥, “バイオ分離工学ハンドブック”, 遠藤 勲, 大矢晴彦, 左右田健次, 橋本 勉編集, サイエンス フォーラム, (1988), p. 214.

49）秋元健吾, 小西恭子, 村上克之, 新免芳史, 小菅康孝, 中矢伸幸, “機能性食品素材の高度分離・精製之開発”, 食品産業ハイセパレーション・システム技術研究組合, (1992), p. 339.
50）久保田昌良, 松崎晴美, 高橋㚌吉, 井上節夫, 化学工学 論文集, 15, 446 (1989).

51) S. Higashidate, Y. Yamauchi, M. Saito, J. Chromatogr, 515, 295 (1990).

52) 井上良計, 韓 力, 亀山 隆, 鹿山 光, 第 36 回油化 学会討論会講演要旨集, 128 (1997).

53）山口道広, 田中 功, 大津 裕, 油化学, 40, 959(1991).

54 ）資生堂, “DHA 高度精製抽出技術開発事業研究報告書 平成 4-6 年度”, p. 231 (1995)

55）門田靖彦, 田中 功, 大津 裕, Chromatography, 117, 298 (1996).

56) 門田靖彦, 田中 功, 大津 裕, 山口道広, 油化学, 46, 25 (1997).

57) R. Yamamura, Y. Shimomura, J. Am. Oil Chem. Soc., 74, 1435 (1997). 


\title{
日本油化学会誌本号掲載 論文要旨
}

\section{[総説］＜wide>無機イオン/界面活性剂ハイブリッド \\ メゾフェーズからの無機多孔体}

尾 関 寿美男

信州大学理学部 (T390-8621 松本市旭 3-1-1)

FSM-16 や MCM-41 のようなメソポーラス無機物質は広い領域の研究者から大きな関心を集めており，分子ふ るい, 吸着剂, クロマト剂, 触媒担体, 触媒としての潜在的な可能性が検討されている。メソポーラス無機物質は 無機イオン/界面活性剂ハイブリッドメゾフェーズ (ISH) を燃やしてつくられる。ISH は多成分系であるため に，合成条件に複雑に依存し，非常に変化に富む構造をとる。われわれはまず，FSM-16 や MCM-41 の調製法を 紹介し，ついでISH の一般的調製法を生成機構とともに述べる。最後に，これまでに調製された ISH を無機イオ ンの種類, メゾフェーズの多形, 形態, 結晶子径および格子定数に注目してまとめる。

(連絡者：尾関寿美男) Vol. 47, No. 5, 429 (1998)

\section{[絵説］単分子膜および LB 膜の光応答機能材料への展開}

\author{
関隆 広
}

東京工業大学資源化学研究所（干226-8503 横浜市緑区長津田町 4259)

LB 法は単なる精緻な分子超構造調製法にとどまらず，物質界面の役割を分子論的に把握する上で極めて貴重な データを与える。特に分子の動きを伴う現象を取り扱う上で, 2 次元組織を与える単分子膜あるいはその LB 膜は 格好の系を与える。この解説では上記の観点から，フォトクロミック単分子膜と LB 膜の最近動向を紹介する。単 分子膜の光力学効果に関する研究及び液晶等分子組織体状態の光制御に関する最新の動向を通じて, 高度な動的分 子システムの構築にLB 法がいかなる役割を果たすことができるかを紹介する。

(連絡者：関 隆広) Vol. 47, No. 5, 441 (1998)

\section{[総説 $]$}

\section{高度不飽和脂肪酸の高度精製技術}

\author{
山村 隆治・下村 泰志 \\ （株）ワイエムシィ（干600-8106 京都市下京区五条烏丸西入醍醐町 284） \\ 連絡先 : T923-0061 石川県小松市国府台 5-28
}

エイコサペンタエン酸 (EPA), ドコサヘキサエン酸 (DHA) やドコサペンタエン酸 (DPA) 含む高度不飽和 脂肪酸 (PUFA) はその生理活性から機能性食品や医薬品として注目を浴びている。中でも医薬品原料として利用 したり，またその機能を確認するためにはPUFA を高度に精製する必要がある。PUFA を高度に精製するため にこれまで多くの検討がなされ EPA のように実用化されているものもある。しかし PUFA の種類や由来する原 料により複雑な好理工程を必要とし，必ずしも大規模精製が完成しているとは言えない。

筆者らは, DHA とn-6 ドコサペンタエン酸 (DPA) を高い含量で含む海生菌から得られた Single Cell Oil エ チルエステルを ODS 充填カラムを用いた工業的規模での分取 HPLC を行い, 分取クロマトだけで高度に分離・精 製された DHA-Eと DPA-E が得られる可能性を見いだした。（連絡者：下村泰志）Vol. 47, No. 5, 449 (1998) 